\title{
Analysis on Level of Safety Performance and Occupants' Satisfaction in Low Cost Housing
}

\author{
Husrul Nizam Husin ${ }^{1,2}$, Abdul Hadi Nawawi², \\ Faridah Ismail2, Natasha Khalil ${ }^{1}$ \\ ${ }^{1}$ Faculty of Architecture, Planning and Surveying, \\ Universiti Teknologi MARA Perak, 32610 Seri Iskandar, Perak, Malaysia \\ 2 Faculty of Architecture, Planning and Surveying, \\ Universiti Teknologi MARA , 40450 Shah Alam, Selangor, Malaysia \\ husrul820@perak.uitm.edu.my.
}

\begin{abstract}
The general building conditions in low cost housing are part of human's quality indicator. However, there are rising issues on the safety performance of the housing since the occupants are inclined to perceive safety hazards. Therefore, this paper explores the concept of Post Occupancy Evaluation (POE) as safety performance tool. This research conducted a survey on safety performance and occupants' satisfaction to 24 numbers of low cost housing at Kuala Lumpur, Malaysia. The correlation result shows that safety performance has a significant relationship with occupants' satisfaction. The findings supported the application of POE as the tool for safety performance.

Keywords: Post Occupancy Evaluation; Low Cost Housing; Safety Performance;Occupants' Satisfaction;

eISSN 2514-751X @ 2018. The Authors. Published for AMER ABRA cE-Bs by e-International Publishing House, Ltd., UK. This is an open-access article under the CC BY-NC-ND license (http://creativecommons.org/licenses/bync-nd/4.0/). Peer-review under responsibility of AMER (Association of Malaysian Environment-Behaviour Researchers), ABRA (Association of Behavioural Researchers on Asians) and CE-Bs (Centre for EnvironmentBehaviour Studies), Faculty of Architecture, Planning \& Surveying, Universiti Teknologi MARA, Malaysia DOI: https://doi.org/10.21834/aje-bs.v3i10.308
\end{abstract}




\subsection{Introduction}

Housing is a foremost universal concern as the wellbeing of a country reflects in its people enjoying a particular standard of living. Residential and neighbourhood satisfactions are important indicators of housing quality and condition which affect individuals' quality of life (Idrus \& Ho, 2008). The factors, which determine their satisfaction levels, are essential inputs in monitoring the success of housing policies. Malaysia is going through a rapid process of population growth and urbanization for several years now. As announced through the Seventh Malaysia's Plan (1996-2000) to Ninth Malaysia's Plan (2006-2010), there is the emergence in low-cost housing construction which is an intentional act as an approach to eradicate squatters or illegal residential, especially in the Klang Valley area. It is inevitable that the Government encourages cooperative housing not only for the lower income groups, but it also caters for the middle-low income groups. Seeing the wavering economic situation, the emerging problem in housing property is the growing demand for better and safe housing. Therefore, it is increasingly important to evaluate housing property for many reasons.

Goh and Ahmad (2012) accentuated that the Human Rights Commission of Malaysia in 2003 criticised the Malaysian government on the failure in addressing issues that relate to the physical safety of occupants. There are also other issues, which were not in-depth consideration such as the habitability, suitability, lack of maintenance, defects and shoddy workmanship in low cost housings. It needs to be set forth that poor quality of a building is much allied to the safety failures of building. This assertion is supported by Abdul-Rahman et al., (1999) and Yau (2006) that indefensible buildings with poor workmanship and low quality of materials also lead to building deterioration and poor aesthetical performance

Therefore, the assessment of safety in low-cost housing is highly relates to the users' behaviour and occupants' feedback. The present research acknowledges Post Occupancy Evaluation (POE) as the best tool to examine the safety performance in low cost housing. Many previous researches (Khalil et al., 2012; Mumovic et al., 2009; Hassanain, 2007; Liu, 2003; Minami, 2007; Altas \& Ozsoy, 1998; Collet da Graca et al., 2007; Gill et al., 2010; Amaratunga \& Baldry, 1999; Foxall \& Hackett, 1994; Goh \& Ahmad, 2012) have showed significant results in optimizing the performance of building by applying POE as the research tool.

\subsection{Post Occupancy Evaluation (POE) as Safety Performance Tool}

Leaman et al. (2010) described that buildings are self-evidently settings or 'contexts' for human activities. Aptly, the impact of strategies in dealing with the safety issues based on the building occupants' experiences needs to be measured. Such assessment is reliable by adopting Post Occupancy Evaluation (POE) as the approach and the best tool to assess safety performance in low cost housing. POE has emerged as a strategic performance measurement tool that is able to examine building performance after the building handed over to the occupants. Regrettably, Way \& Bordass (2005) identified that the postconstruction stage of a building is the most neglected stage, and it is often looked upon as a nuisance and a distraction. POE encompasses a comprehensive review of the building 
details covering the technical performance, users' satisfactions, project delivery process and recommendation for the action.

Many agencies, especially in developed countries such as the UK, USA, Canada and Australia, are using information from POE in support of the design criteria and guidelines (Khalil et al., 2012). POE programmes were conducted after construction stage to identify mistakes and lessons learned by analysis of findings.

\subsection{The Fundamental Concept: Building Users/Occupants' Feedback}

The primary concept and process in POE is to illustrate significant considerations for the evaluation to ensure the accuracy in the method used. The main considerations of the POE criteria are to define the case study or building and the inputs needed from the building users, i.e. their feedback. The criteria for judgement are the fulfilment of the occupants' needs that POE is focusing on assessment of client's satisfaction and functional 'fit' (Zimmerman \& Martin, 2001). Therefore, the fundamental concepts of POE stress the importance of feedback data from the building users. However, Bordass and Leaman, (2005a) believed that data and knowledge management tend to be relatively weak in most building-related organizations. Consequently, the project management team would decide to give their concentration on immediate clients as the team would be able to put their experience and a new understanding into action immediately (Bordass \& Leaman, 2005a).

There were many instruments that can be utilised in gathering feedbacks from building users including individual surveys, focus groups, interviews and users' satisfaction surveys (Bordass \& Leaman, 2005a; Eley, 2001; Watson, 1996; Watson, 2003). The concept of POE in getting feedback from the users helps to feed the inputs into the completed project and much can be learnt for reuse in future studies (Khalil et al., 2012). However, for the most part, building users have not engaged directly with the performance of the end product. Building stakeholders must aware to the concept of POE as this tool able to provide extensive benefits that can maintain the sustainability of the building, including the safety aspects.

\subsection{Research Objectives}

The main aim of this research is to develop a Post Occupancy Evaluation (POE) framework that integrates safety elements for low cost housing $(\mathrm{LCH})$ in Malaysia. The research objectives are as follows:

- To identify the concept of Post Occupancy Evaluation (POE) in relation to safety performance

- To identify the safety elements and attributes in low cost housing

- To determine the correlation between the level of safety performance attributes and the occupants' satisfaction level

\subsection{Methodology}

This study employs the mixed-method approach; using both qualitative and quantitative analysis. It begins with preliminary survey stage, where the questionnaire survey and semi- 
structured interviews is used as instrument, to the building experts. The experts are professionals that working in organizations involving PPR housing development management, including from KPKT, DBKL, CIDB and also professionals builders in private construction firms. Result and findings from preliminary survey has confirmed the suitability of the construct safety elements and attributes. The list safety elements and attributes are then included in the survey forms for Main Survey, i.e. Safety Performance Inspection Survey (SPIS) and Occupants Satisfaction Survey (OSS). The main objective of SPIS is to obtain the safety performance score of the attributes using numerated performance scale, via condition inspection to the housing area. While the OSS is use to determine occupants' satisfaction level of the validated safety attributes and distributed the questionnaires to the identified occupants.

\subsection{Results and Discussions}

The analysis of the main survey entails into three parts; i.e. i) Result of Safety Performance Survey, ii) Result of Occupants' Satisfaction Survey, and iii) Correlation Result of Safety Performance and Occupants Satisfaction. The first part describes the analysis of safety performance level for each safety attributes. The inspection survey is carried out by nominated and reliable professional surveyors. The second part of the analysis reveals the level of occupants' satisfaction towards the safety attributes. Finally, the last part of this analysis reveals the findings of correlation between the safety performance scale and the occupants' satisfaction level, based on the similar safety attributes for the sample of housing units. There are twenty-four (24) low cost housing determined in this survey; namely Projek Perumahan Rakyat (PPR) (see Table 1). PPR is located in the Federal Territory of Kuala Lumpur, and it is a Government program to accommodate and meet the needs of all slum dwellings for low-income earners. The National Housing Department (JPN), alongside the Ministry of Housing and Local government are the implementing agencies for PPR projects across Malaysia. Most of the PPR tenants opt for the rental basis with only a segment of the tenants bought and own the units. Kuala Lumpur is the capital and the largest city of Malaysia covering a land area of $244 \mathrm{sq} \mathrm{km}(94 \mathrm{sq} \mathrm{mi})$, with a population of 1.63 million according to census projections in 2010 (Junaidi, Fauzi, \& Ghazali, 2012).

Table 1. Information of Program Perumahan Rakyat (PPR) housing projects (housing samples)

\begin{tabular}{|c|l|c|c|c|c|}
\hline NO. & \multicolumn{1}{|c|}{ HOUSING PROJECTS } & $\begin{array}{c}\text { TOTAL } \\
\text { NO. OF } \\
\text { UNIT }\end{array}$ & $\begin{array}{c}\text { TOTAL } \\
\text { NO. OF } \\
\text { BLOCK }\end{array}$ & $\begin{array}{c}\text { DATE OF HAND- } \\
\text { OVER }\end{array}$ & $\begin{array}{c}\text { SAMPLE } \\
\text { SIZE (s) }\end{array}$ \\
\hline & ZONE 1 & & & & \\
\hline 1 & PPR Kg. Muhibbah, Jalan Puchong & 2,844 & 9 & 22.12 .2006 & 20 \\
\hline 2 & PPR Malaysia Permai (PPR Raya Permai) & 1,264 & 4 & 2.06 .2006 & 20 \\
\hline 3 & PPR Sg. Besi (PPR Desa Petaling) & 632 & 2 & 19.08 .2002 & 10 \\
\hline 4 & PPR Pudu Hulu & 948 & 3 & 15.01 .2003 & 20 \\
\hline 5 & PPR Seri Malaysia & 632 & 2 & 03.1 .2007 & 10 \\
\hline 6 & $\begin{array}{l}\text { PPR Jn. Lapangan Terbang Lama Fasa 1 } \\
\text { (PPR Seri Alam) }\end{array}$ & 660 & 5 & 29.04 .2004 & 20 \\
\hline
\end{tabular}


Husin, H.Z., et.al. / Asian Journal of Environment-Behaviour Studies (ajE-Bs), 3(10) Sep / Oct 2018 (p10-20)

\begin{tabular}{|c|c|c|c|c|c|}
\hline 7 & $\begin{array}{l}\text { PPR Jln Cochrane (PPR Laksamana \& } \\
\text { PPR Perkasa) }\end{array}$ & 1,620 & 5 & 25.04 .2005 & 20 \\
\hline \multirow[t]{2}{*}{8} & $\begin{array}{l}\text { PPR JIn. Lapangan Terbang Lama Fasa } 2 \\
\text { (PPR Seri Alam 2) }\end{array}$ & 920 & 7 & 12.07 .2010 & 20 \\
\hline & ZONE 2 & & & & \\
\hline 9 & PPR KL Linear City 1 (PPR Seri Anggerik) & 316 & 1 & 15.01 .2003 & 10 \\
\hline 10 & $\begin{array}{l}\text { PPR KL Linear City li Fasa } 1 \text { (PPR Pantai } \\
\text { Ria) }\end{array}$ & 1,264 & 4 & 08.08 .2007 & 20 \\
\hline 11 & PPR Lembah Pantai, Kerinchi & 1,896 & 6 & 31.3.2007 & 20 \\
\hline 12 & $\begin{array}{l}\text { PPR KL Linear City li Fasa } 2 \text { (PPR Seri } \\
\text { Cempaka) }\end{array}$ & 632 & 2 & 08.08 .2007 & 10 \\
\hline 13 & PPR Salak Selatan & 632 & 2 & 24.06 .2004 & 10 \\
\hline \multirow[t]{2}{*}{14} & PPR Kg. Limau, Pantai Dalam & 632 & 2 & 15.1.2005 & 10 \\
\hline & ZONE 3 & & & & \\
\hline 15 & PPR Taman Intan Baiduri & 1,834 & 6 & 15.04.2004 & 20 \\
\hline 16 & PPR Taman Wahyu I (PPR Beringin) & 1,896 & 6 & 31.03 .2003 & 20 \\
\hline 17 & PPR Pekan Batu & 632 & 2 & 03.12 .2002 & 10 \\
\hline 18 & PPR Taman Wahyu II (PPR Wahyu) & 948 & 3 & 07.04 .2002 & 20 \\
\hline 19 & PPR Kg Batu Muda (SPNB) & 2,132 & 7 & 31.12 .2006 & 20 \\
\hline \multirow[t]{2}{*}{20} & PPR Pekan Kepong & 948 & 3 & 08.04 .2010 & 10 \\
\hline & ZONE 4 & & & & \\
\hline 21 & PPR Ampang Hilir (PPR Hiliran Ampang) & 948 & 3 & 16.12 .2004 & 10 \\
\hline 22 & PPR Kg. Baru Air Panas & 2,528 & 8 & 1.05 .2007 & 20 \\
\hline 23 & PPR Sg. Bonus, Air Jernih & 632 & 2 & 14.02 .2005 & 10 \\
\hline 24 & PPR Seri Semarak & 1,580 & 5 & 14.02 .2005 & 20 \\
\hline \multicolumn{2}{|c|}{ TOTAL } & 28,970 & 99 & - & 380 \\
\hline
\end{tabular}

Based on Table 1, the housing projects were hand over to the tenants beginning 2002 to 2010. Therefore, the occupancy period of the housing range from 2 years to 10 years. The sample size determined in both surveys (i.e. SPIS and OSS) is 380 samples; using the formula by Krejcie and Morgan (1970).

\subsection{Results on Safety Performance Survey}

In this section, each attribute derived from the results of preliminary survey is use for the safety performance inspection in the identified building. There are 24 safety attributes listed in the survey form, and the rating of each attribute in the relative safety elements refers to the scale value of Safety Performance Index (SPI). The constructed SPI is adapt from previous schemes; CSP1Matrix (Che-Ani et al., 2010) and Housing Performance Evaluation Model (HPEM) (Kim et al., 2005). Table 2 illustrates the result of safety performance level for the construct safety attributes:

Table 2 depicts the result of safety performance level for all samples of housing units demonstrating the results for Attributes under Performance as safety category. Based on the result, the rating for several items as "good" performance are; column/beam $(68 \%)$, roof $(65 \%)$, slabs $(49 \%)$ and plumbing system $(61 \%)$. The scale ratings as "moderate" performance are fire system (52\%), corridor (66\%), staircase $(59 \%)$, balcony $(65 \%)$, playground $(61 \%)$, and vehicle parking $(57 \%)$. Two items were highly marked as "poor" performance; electrical services (39\%) and lift (66\%). For the safety category of Quality, the result presents that all attributes under the Fittings elements are highly rated as "good" 14 
performance; i.e. door/window (74\%), security /metal grille (77\%) and, sanitary fitting (58\%). The rest of the attributes under this quality category were substantially rate as "moderate" performance. It describes that these items have moderate defects but may become severe if left unattended. Even though a majority of the items under this category are within moderate performance, this supports the probable change for the users' requirements.

Table 2. Descriptive result of safety performance level of all attributes

\begin{tabular}{|c|c|c|c|c|c|c|c|}
\hline \multirow{2}{*}{ CATEGORY } & \multirow{2}{*}{ ELEMENTS } & \multirow{2}{*}{ ATTRIBUTES } & \multicolumn{5}{|c|}{ SCALE OF SAFETY PERFORMANCE INDEX (SPI) } \\
\hline & & & $\begin{array}{l}\text { Very } \\
\text { poor }\end{array}$ & Poor & Moderate & Good & Very Good \\
\hline \multirow{12}{*}{ 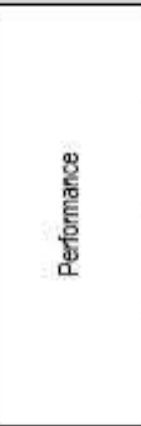 } & \multirow{3}{*}{ Structural } & Column / beam & $0 \%$ & $4 \%$ & $26 \%$ & $68 \%$ & $1 \%$ \\
\hline & & Roof & $0 \%$ & $6 \%$ & $29 \%$ & $65 \%$ & $0 \%$ \\
\hline & & Slabs & $0 \%$ & $10 \%$ & $40 \%$ & $49 \%$ & $0 \%$ \\
\hline & \multirow{3}{*}{ Services } & Electrical Services & $0 \%$ & $39 \%$ & $23 \%$ & $37 \%$ & $0 \%$ \\
\hline & & Piumbing System & $0 \%$ & $10 \%$ & $29 \%$ & $61 \%$ & $0 \%$ \\
\hline & & Fire System & $0 \%$ & $24 \%$ & $52 \%$ & $24 \%$ & $0 \%$ \\
\hline & \multirow{3}{*}{ Space } & Corridor & $0 \%$ & $3 \%$ & $66 \%$ & $31 \%$ & $0 \%$ \\
\hline & & Staincase & $0 \%$ & $19 \%$ & $59 \%$ & $22 \%$ & $0 \%$ \\
\hline & & Baloony & $0 \%$ & $13 \%$ & $65 \%$ & $22 \%$ & $0 \%$ \\
\hline & \multirow{3}{*}{ Amenities } & Playground & $1 \%$ & $20 \%$ & $61 \%$ & $18 \%$ & $0 \%$ \\
\hline & & Vehicle Parking & $3 \%$ & $26 \%$ & $57 \%$ & $14 \%$ & $0 \%$ \\
\hline & & Lift & $23 \%$ & $66 \%$ & $8 \%$ & $3 \%$ & $0 \%$ \\
\hline \multirow{12}{*}{ 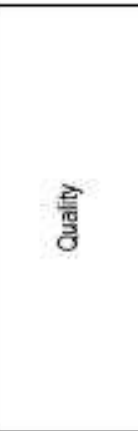 } & \multirow{3}{*}{ Fittings } & Door / Windou & $0 \%$ & $9 \%$ & $16 \%$ & $74 \%$ & $0 \%$ \\
\hline & & Security bar fgrille & $0 \%$ & $2 \%$ & $21 \%$ & $77 \%$ & $0 \%$ \\
\hline & & Sanitary Fittings & $0 \%$ & $16 \%$ & $26 \%$ & $58 \%$ & $0 \%$ \\
\hline & \multirow{3}{*}{ Materials } & Floor Finishes & $0 \%$ & $12 \%$ & $48 \%$ & $39 \%$ & $2 \%$ \\
\hline & & Wal Finishes & $0 \%$ & $13 \%$ & $48 \%$ & $37 \%$ & $2 \%$ \\
\hline & & Ceiling Finishes & $2 \%$ & $34 \%$ & $36 \%$ & $27 \%$ & $1 \%$ \\
\hline & \multirow{3}{*}{ Environment } & Internal Ventilation & $0 \%$ & $6 \%$ & $59 \%$ & $35 \%$ & $0 \%$ \\
\hline & & $\begin{array}{l}\text { Indoor } \\
\text { Temperature }\end{array}$ & $0 \%$ & $15 \%$ & $43 \%$ & $42 \%$ & $0 \%$ \\
\hline & & Visual Obstruction & $0 \%$ & $18 \%$ & $47 \%$ & $34 \%$ & $0 \%$ \\
\hline & \multirow{3}{*}{ Workmanship } & Plastering Works & $0 \%$ & $17 \%$ & $48 \%$ & $35 \%$ & $0 \%$ \\
\hline & & Tiling Works & $0 \%$ & $9 \%$ & $51 \%$ & $41 \%$ & $0 \%$ \\
\hline & & Painting Works & $0 \%$ & $17 \%$ & $61 \%$ & $23 \%$ & $0 \%$ \\
\hline
\end{tabular}

\subsection{Results on Occupants' Satisfaction Survey}

In occupants' satisfaction survey, the respondents are require to rate their satisfaction level for 24 safety attributes. The safety attributes are similar to the attributes outlined in the SPIS. The respondents were need to rate their satisfaction level based on five numerical Likertscale; "1" (Very dissatisfied), "2" (Dissatisfied), "3" (Moderately satisfied), "4" (Satisfied), and "5" (Very satisfied. Table 3 illustrates the occupants' satisfaction level towards the listed safety attributes: 
Husin, H.Z., et.al. / Asian Journal of Environment-Behaviour Studies (ajE-Bs), 3(10) Sep / Oct 2018 (p10-20)

Table 3. Descriptive Result of Occupants' Satisfaction Level

\begin{tabular}{|c|c|c|c|c|c|c|c|}
\hline \multirow[b]{2}{*}{$\begin{array}{c}\text { Safety } \\
\text { Elements }\end{array}$} & \multirow[b]{2}{*}{ Safety Attributes } & \multicolumn{5}{|c|}{ Percentage Result For Occupants' Satisfaction Level } & \multirow{2}{*}{$\begin{array}{l}\text { Missing } \\
\text { No } \\
\text { answer }\end{array}$} \\
\hline & & $\begin{array}{c}\text { Very } \\
\text { Dissatisfied } \\
\text { (1) }\end{array}$ & $\begin{array}{l}\text { Dissatisfied } \\
\text { (2) }\end{array}$ & $\begin{array}{l}\text { Moderately } \\
\text { Satisfied } \\
\text { (3) }\end{array}$ & $\begin{array}{l}\text { Satisfied } \\
\text { (4) }\end{array}$ & $\begin{array}{c}\text { Very } \\
\text { Satisfied } \\
\text { (5) }\end{array}$ & \\
\hline \multirow{3}{*}{ Structural } & Column / beam & $0.5 \%$ & $6.1 \%$ & $29.5 \%$ & $60.5 \%$ & $26 \%$ & $0.8 \%$ \\
\hline & Roof & $0.3 \%$ & $7.1 \%$ & $30.8 \%$ & $59.2 \%$ & $1.6 \%$ & $1.1 \%$ \\
\hline & Slabs & $0.5 \%$ & $8.7 \%$ & $38.7 \%$ & $48.2 \%$ & $24 \%$ & $1.6 \%$ \\
\hline \multirow{3}{*}{ Senices } & Electrical Services & $0.5 \%$ & $33.2 \%$ & $25.5 \%$ & $37.9 \%$ & $21 \%$ & $0.8 \%$ \\
\hline & Plumbing System & $1.6 \%$ & $124 \%$ & $28.9 \%$ & $54.7 \%$ & $1.6 \%$ & $0.8 \%$ \\
\hline & Fire System & $0.5 \%$ & $20.5 \%$ & $47.4 \%$ & $29.7 \%$ & $1.1 \%$ & $0.8 \%$ \\
\hline \multirow{3}{*}{ Space } & Conidor & $0.5 \%$ & $7.1 \%$ & $59.5 \%$ & $30.8 \%$ & $0.8 \%$ & $1.3 \%$ \\
\hline & Staircase & $1.1 \%$ & $20.3 \%$ & $53.7 \%$ & $23.2 \%$ & $0.0 \%$ & $1.8 \%$ \\
\hline & Balcony & $0.8 \%$ & $13.2 \%$ & $58.4 \%$ & $24.5 \%$ & $0.5 \%$ & $2.6 \%$ \\
\hline \multirow{3}{*}{ Amenities } & Playground & $4.7 \%$ & $23.9 \%$ & $53.4 \%$ & $15.8 \%$ & $1.3 \%$ & $0.8 \%$ \\
\hline & Vehicle Parking & $1.8 \%$ & $13.7 \%$ & $53.4 \%$ & $28.2 \%$ & $1.1 \%$ & $1.8 \%$ \\
\hline & Lift & $18.7 \%$ & $621 \%$ & $13.4 \%$ & $3.7 \%$ & $0.8 \%$ & $1.3 \%$ \\
\hline \multirow{3}{*}{ Fittings } & Door / Window & $0.5 \%$ & $10.0 \%$ & $23.4 \%$ & $64.7 \%$ & $0.8 \%$ & $0.5 \%$ \\
\hline & $\begin{array}{l}\text { Security bar ! } \\
\text { Metal grile }\end{array}$ & $1.3 \%$ & $5.3 \%$ & $24.2 \%$ & $67.4 \%$ & $1.8 \%$ & - \\
\hline & Sanitary Fitings & $0.3 \%$ & $15.0 \%$ & $30.8 \%$ & $53.2 \%$ & $0.8 \%$ & - \\
\hline \multirow{3}{*}{ Materials } & Floor Finishes & $0.5 \%$ & $10.3 \%$ & $49.5 \%$ & $37.9 \%$ & $1.8 \%$ & - \\
\hline & Wall Finishes & $0.5 \%$ & $118 \%$ & $46.3 \%$ & $39.5 \%$ & $1.6 \%$ & $0.3 \%$ \\
\hline & Celing Finishes & $1.8 \%$ & $221 \%$ & $40.8 \%$ & $33.7 \%$ & $1.3 \%$ & $0.3 \%$ \\
\hline \multirow{3}{*}{ Environment } & $\begin{array}{c}\text { Internal } \\
\text { Ventilation }\end{array}$ & $1.3 \%$ & $7.1 \%$ & $55.0 \%$ & $35.8 \%$ & $0.5 \%$ & $0.3 \%$ \\
\hline & $\begin{array}{c}\text { Indoor } \\
\text { Temperature }\end{array}$ & $0.5 \%$ & $15.0 \%$ & $40.8 \%$ & $42.4 \%$ & $0.5 \%$ & $0.8 \%$ \\
\hline & Visual Obstruction & $0.8 \%$ & $21,1 \%$ & $42.6 \%$ & $33.2 \%$ & $1.8 \%$ & $0.5 \%$ \\
\hline \multirow{3}{*}{ Workmanship } & Plastering Works & $1.3 \%$ & $124 \%$ & $48.7 \%$ & $34.7 \%$ & $0.5 \%$ & $2.4 \%$ \\
\hline & Tling Works & $0.5 \%$ & $10.3 \%$ & $50.0 \%$ & $36.8 \%$ & $1.3 \%$ & $1.1 \%$ \\
\hline & Painting Works & $0.5 \%$ & $16.1 \%$ & $54.7 \%$ & $27.1 \%$ & $0.8 \%$ & $0.8 \%$ \\
\hline
\end{tabular}

Results from Table 3 indicate a higher proportion of satisfied respondents in attributes of Column/beam, Roof, Slabs, Electrical services and Plumbing system. However, 47.4\% respondents (179 out of 380 respondents) are moderately satisfied with the Fire system. Additionally, it shows that more than $50 \%$ of the respondents are moderately satisfied for the attributes of Corridor, Staircase, Balcony, Playground, and Vehicle Parking. It is worthy to highlight that, $80.80 \%$ of the respondents (a total from $62.1 \%$ of dissatisfied and $18.7 \%$ of very dissatisfied respondents) had expressed their dissatisfaction with Lift. The respondents claimed that their dissatisfaction with the performance of the lift is due to regularly not functioning well and experience frequent break down. Results in Table 3 also illustrate Security Bar/Metal Grille receives the highest proportion of satisfied respondents as compared to Door/Window (64.7\%), Sanitary Fittings (53.2\%) and Indoor temperature (42.4\%). There are eight attributes, which the respondents, are moderately satisfied with; Floor Finishes, Wall Finishes, Ceiling Finishes, Internal Ventilation, Visual Obstruction, Plastering Works, Tiling Works, and Painting Works. None of the attributes under this quality category constitutes a major proportion of dissatisfaction from the respondents. 


\subsection{Correlation Result of Safety Performance and Occupants' Satisfaction}

The final section of the analysis illustrates the correlation between SPIS OSS. The Spearman rho $(r)$ is use in the analysis since both variables consist of ordinal scales derived from random sampling of housing units and respondents. The correlation test conducts to investigate whether there is a significant relationship between the safety performance level and the occupants' satisfaction level with similar safety attributes. The research hypothesis and the null hypothesis of the study are as followed:

- $\mathrm{H}_{1}=$ there is a significant relationship between the safety performance of the low cost housing, and the occupants' satisfaction with regards to the safety performance.

- $\mathrm{H}_{0}=$ there is no relationship between the safety performance of the low cost housing, and the occupants' satisfaction with regards to the safety performance.

According to Chua (2008), the result from the Spearman correlation shows the strength of the relationship of two variables by referring to its correlation coefficient value of spearman rho (r). The significance level of the variables is tested with two-tailed with a significant correlation value at .01 level (2-tailed). The correlation analysis was reported in two divisions of safety categories namely; performance category and quality category. There are twelve safety attributes under each category validated from the preliminary survey. The analysis of the correlation is using statistical software program SPSS (Statistical Packages for the Social Sciences, versions 16.00). The hypotheses were statistically test with a two-tailed alpha level of 0.05 .

Table 4. Correlation result of Safety performance and Occupants' Satisfaction (Performance category)

\begin{tabular}{|c|c|c|c|c|c|c|c|c|c|c|c|c|}
\hline $\begin{array}{l}\text { Attributea for } \\
\text { Safety } \\
\text { Performance }\end{array}$ & $\begin{array}{l}\text { Coll } \\
\text { Beam }\end{array}$ & Roof & Slabs & $\begin{array}{l}\text { Elect } \\
\text { sec }\end{array}$ & $\begin{array}{l}\text { Plumb } \\
\text { sya }\end{array}$ & $\begin{array}{l}\text { Fire } \\
\text { gya }\end{array}$ & cort & stair & Bal & $\begin{array}{l}\text { Play } \\
\text { ged }\end{array}$ & $\begin{array}{l}\text { Yed } \\
\text { park }\end{array}$ & Lift \\
\hline $\begin{array}{l}\text { Correastion } \\
\text { Coesficient }\end{array}$ & $652^{-}$ & $714^{-}$ & $670^{-}$ & $.633^{-}$ & $.625^{-}$ & $703^{-}$ & $.624^{-}$ & $.645^{-}$ & 847 & $493^{-}$ & $297^{-}$ & 434 \\
\hline Sig. [2tailed] & .000 & .000 & .000 & .000 & .000 & .000 & .000 & .000 & .000 & .000 & .000 & .000 \\
\hline $\begin{array}{l}\text { Attributes for } \\
\text { Occupants' } \\
\text { Satisfaction }\end{array}$ & $\begin{array}{l}\text { Coll } \\
\text { Beam }\end{array}$ & Roof & Slabs & $\begin{array}{l}\text { Elect } \\
\text { secy }\end{array}$ & $\begin{array}{l}\text { Plumb } \\
\text { sys }\end{array}$ & $\begin{array}{l}\text { Fire } \\
\text { вys }\end{array}$ & core & stair & Bal & $\begin{array}{l}\text { Play } \\
\text { ged }\end{array}$ & $\begin{array}{l}\text { Yeh } \\
\text { park }\end{array}$ & Lift \\
\hline
\end{tabular}

Table 5. Correlation result of Safety performance and Occupants' Satisfaction (Quality category)

\begin{tabular}{|c|c|c|c|c|c|c|c|c|c|c|c|c|}
\hline $\begin{array}{l}\text { Attributes for } \\
\text { Safety } \\
\text { Performance }\end{array}$ & $\begin{array}{l}\text { Door I } \\
\text { Window }\end{array}$ & $\begin{array}{l}\text { Security } \\
\text { barl } \\
\text { Metal } \\
\text { grille }\end{array}$ & $\begin{array}{l}\text { San } \\
\text { Fit }\end{array}$ & $\begin{array}{l}\text { Floor } \\
\text { Fin. }\end{array}$ & $\begin{array}{l}\text { Wall } \\
\text { Fin. }\end{array}$ & $\begin{array}{l}\text { Gei } \\
\text { Fin. }\end{array}$ & $\begin{array}{l}\text { Inter } \\
\text { Vent. }\end{array}$ & $\begin{array}{l}\text { Indoor } \\
\text { Temp. }\end{array}$ & $\begin{array}{c}\text { Vis } \\
\text { Opats }\end{array}$ & $\begin{array}{l}\text { Plaster } \\
\text { Works }\end{array}$ & $\begin{array}{l}\text { Tiling } \\
\text { Works }\end{array}$ & $\begin{array}{l}\text { Paint } \\
\text { Works }\end{array}$ \\
\hline $\begin{array}{l}\text { Correlation } \\
\text { Coeficient: }\end{array}$ & $.592^{-}$ & $.595^{\circ}$ & 722 & $664^{\prime \prime}$ & $682^{-}$ & .581 & $689^{-}$ & $654^{-}$ & $.682^{-}$ & $652^{-}$ & $657^{-}$ & $.703^{-1}$ \\
\hline Sig [2tailed] & .000 & .000 & 000 & .000 & .000 & .000 & .000 & .000 & .000 & .000 & .000 & .000 \\
\hline $\begin{array}{l}\text { Attributes for } \\
\text { Occupants' } \\
\text { Satisfaction }\end{array}$ & $\begin{array}{l}\text { Door I } \\
\text { Window }\end{array}$ & $\begin{array}{c}\text { Security } \\
\text { bari } \\
\text { Metal } \\
\text { grille }\end{array}$ & $\begin{array}{l}\text { San } \\
\text { Fit }\end{array}$ & $\begin{array}{l}\text { Floor } \\
\text { Fin. }\end{array}$ & $\begin{array}{l}\text { Wall } \\
\text { Fin. }\end{array}$ & $\begin{array}{l}\text { Coi } \\
\text { Fin. }\end{array}$ & $\begin{array}{l}\text { Inter } \\
\text { Vent. }\end{array}$ & $\begin{array}{l}\text { Indoor } \\
\text { Temp. }\end{array}$ & $\begin{array}{l}\text { Vis } \\
\text { Obats }\end{array}$ & $\begin{array}{l}\text { Plaster } \\
\text { Works }\end{array}$ & $\begin{array}{l}\text { Tiling } \\
\text { Works }\end{array}$ & $\begin{array}{l}\text { Paint } \\
\text { Works }\end{array}$ \\
\hline
\end{tabular}

Table 4 and Table 5 show the results of Spearman correlation test in SPIS and OSS as the tested variables. It shows that a majority of the attributes of occupants' satisfaction level is positively correlates with safety performance level in the housing unit. For the Performance 
category (see Table 4), the correlation coefficient of the attributes indicates an average and strong correlational value. The highest correlation coefficient indicated for the attribute is Roof, with a significant value of $r=0.714$. The categorization of attributes as "average" strength are; Column/Beam, Slabs, Electrical services, Plumbing system, Fire system, Corridor, Staircase and Balcony, with coefficient range from 0.624 to 0.703 . All of the variables has a significant relationship (Sig. $=0.000$ ), even though some of the variables has a weak correlation strength (Playground, $r=0.493$, Vehicle Parking, $r=0.297$, Lift, $r=0.434$ ). Despite having weak correlation, these attributes have very significant relationships and supported the research hypothesis. It also illustrates that the null hypothesis was successfully rejected, and this research decides that there is a significant relationship between the attributes for both variables. Almost similar to the result as in Performance category, majority of the attributes in Quality category (see Table 5) is positively correlates with safety performance level. In terms of correlational strength, only the variable of Sanitary Fittings has a strong relationship, with $r=0.722$. The rest of the attributes, i.e. Door / window, Security bar / metal grille, Floor finishes, Wall finishes, Ceiling finishes, Internal ventilation, Indoor temperature, Visual obstruction, Plastering works, Tiling works and Painting work, were categorized as average strength with coefficient values ranging from 0.582 to 0.703 .

Despite the findings resulted a moderate correlational strength, it was found that all of the variables have a significant relationship (Sig.=.000). The lowest correlation coefficient indicated based on the result is Ceiling Finishes, with $r=0.581$. Both results in the above correlational analysis show significant relationships between both variables, i.e. safety performance level and occupants' satisfaction level. This result has lucratively rejects the null hypothesis. Therefore, there is a significant relationship between the two variables; hence this result supports the research hypothesis. Since the correlation result only provides the value of coefficient and the strength of relationship, the researcher predicts that the level of occupants' satisfaction depends upon the level of safety performance in their housing unit.

\subsection{Conclusion}

The correlation analysis resolves to support the application of Post Occupancy Evaluation (POE) as the tool for safety performance assessment of low cost housing. Since POE grants the participations from the building users or building occupants as the assessment's execution, the relationship between the result of the safety conditions and the occupants' satisfaction validates the theoretical basis of POE as the safety assessment. All of the surveys and presentation of results were aligned with the vital phases being highlighted in POE concept; planning phase, conducting phase and applying phase. Therefore, the findings show that that the level of occupants' satisfaction depends upon the level of safety performance in their housing unit. Indirectly, it also shows the relevance of POE by incorporating participation of occupants, as the safety performance tool for this study. 


\section{Acknowledgement}

The authors wish to acknowledge the support grant in performing this study under the Exploratory Research Grant Scheme (ERGS) Phase 1/2011 funded by the Ministry of Higher Education, Malaysia (KPT) and to Universiti Teknologi MARA, Perak.

\section{References}

Abdul-Rahman, H., Kwan, C. L., \& Woods, P. C. (1999). Quality function deployment in construction design: application in low-cost housing design. International Journal of Quality \& Reliability Management, 16(6), 591-605.

Altas, N. E., \& Ozsoy, A. (1998). Spatial Adaptability and Flexibility as Parameters of User Satisfaction for Quality Housing. Building and Environment, 33(5), 315-323.

Amaratunga, D., \& Baldry, D. (1999). Building Performance Evaluation In Higher Education Properties: Towards A Process Model. In COBRA 1999.

Bordass, B., \& Leaman, A. (2005). Making feedback and post-occupancy evaluation routine 1: A portfolio of feedback techniques. Building Research \& Information, 33(4), 347-352. doi:10.1080/09613210500162016

Che-Ani, A. I., Ali, A. S., Tahir, M. M., Abdullah, N. A. G., \& Tawil, N. M. (2010). The Development of a Condition Survey Protocol (CSP) 1 Matrix for Visual Building Inspection. In The Construction, Building and Real Estate Research Conference of the Royal Institution of Chartered Surveyors (COBRA2010), 2-3 September 2010 (pp. 822). Dauphine Université, Paris.

Chua, Y. P. (2008). Asas Statistik Penyelidikan: Analisis Data Skala Ordinal dan Skal Nominal (Kaedah dan Statistik Penyelidikan. Buku 3). McGraw Hill, Malaysia.

Collet da Graca, V. A., Kowaltowski, D. C. C. K., \& Petreche, J. R. D. (2007). An evaluation method for school building design at the preliminary phase with optimisation of aspects of environmental comfort for the school system of the State Sao Paulo in Brazil. Building and Environment, 42, 984-999. doi:10.1016/j.buildenv.2005.10.020

Eley, J. (2001). How do post-occupancy evaluation and the facilities manager meet? Building Research \& Information, 29(2), 164-167. doi:10.1080/09613210010016848

Foxall, G., \& Hackett, P. (1994). Consumer Satisfaction with Birmingham 's International Convention Centre. The Service Industries Journal, 14(3), 369-380.

Gill, Z. M., Tierney, ichael J., Pegg, I. M., \& Allan, N. (2010). Low-energy dwellings : the contribution of behaviours to actual performance. Building Research \& Information, 38(5), 491-508. doi:10.1080/09613218.2010.505371

Goh, A. T., \& Ahmad, Y. (2012). Public Low-Cost Housing In Malaysia: Case Studies On Ppr Low-Cost Flats In Kuala Lumpur (pp. 1-18). Kuala Lumpur. Retrieved from fbe.um.edu.myimagesfabFilesjdbevol8vol8-01.pdf MALAYSIA

Government of Malaysia. (1996). Seventh Malaysia Plan (1996-2000). Jabatan Percetakan Negara, Kuala Lumpur.

Government of Malaysia. (2006). Ninth Malaysia Plan (2006-2010). Jabatan Percetakan Negara, Kuala Lumpur.

Hassanain, M. A. (2007). Post-Occupancy Indoor Environmental Quality Evaluation of Student Housing Facilities. Architectural Engineering and Design Management, 3(4), 249-256. 
Idrus, N., \& Ho, C. S. (2008). Affordable And Quality Housing Through The Low Cost Housing Provision In Malaysia. In Seminar of Sustainable Development and Governance, Department of Civil Engineering, and Architecture, Toyohashi University of Technology, 26 June 2008 (pp. 1-21).

Junaidi, A. B., Fauzi, R., \& Ghazali, A. S. (2012). Penilaian awal impak perlaksanaan Dasar Perumahan Negara terhadap sektor perumahan di Kuala Lumpur. GEOGRAFIA Online Malaysia Journal of Society and Space, 6(6), 90-108.

Khalil, N., Husin, H. N., \& Nawawi, A. H. (2012). An Analytical Literature: Strategic Improvement of Sustainable Building Performance Tool for Malaysia's Higher Institutions. Procedia - Social and Behavioral Sciences, 36(June 2011), 306-313. doi:10.1016/j.sbspro.2012.03.034

Kim, S. S. S., Yang, I. I. H., Yeo, M. M. S., \& Kim, K. K. W. (2005). Development of a housing performance evaluation model for multi-family residential buildings in Korea. Building and Environment, 40(8), 1103-1116. doi:10.1016/j.buildenv.2004.09.014

Krejcie, R. V, \& Morgan, D. W. (1970). Determining sample size. Educational and Psychological Measurement, 38, 607-610.

Leaman, A., Stevenson, F., \& Bordass, B. (2010). Building evaluation: practice and principles. Building Research \& Information, 38(5), 564-577. doi:10.1080/09613218.2010.495217

Liu, A. M. M. (2003). The quest for quality in public housing projects: a behaviour-to-outcome paradigm. Construction Management and Economics, 21, 147-158. doi:10.1080/0144619032000049700

Minami, K. (2007). A Post-Occupancy Evaluation of Layout Changes Made to KEP Adaptable Housing. Journal of Asian Architecture and Building Engineering (JAABE), 6(2), 245-250.

Mumovic, D., Davies, M., Ridley, I., Altamirano-Medina, H., \& Oreszczyn, T. (2009). A methodology for postoccupancy evaluation of ventilation rates in schools. Building Serv. Eng. Res. Technol., 30(2), 143-152.

Watson, C. (2003). Review Of Building Quality Using Post Occupancy Evaluation. Journal of the Programme on Educational Building, (OECD, Paris). Retrieved September 10, 2008, from http://www.postoccupancyevaluation.com/publications/pdfs/POE OECD V4.pdf

Watson, C. G. (1996). Evolving Design For Changing Values And Ways Of Life. In IAPS 14 Conference (pp. 1-10). Stockholm.

Way, M., \& Bordass, B. (2005). Making feedback and post-occupancy evaluation routine 2: Soft landings - involving design and building teams in improving performance. Building Research \& Information, 33(4), 353-360. doi:10.1080/09613210500162008

Yau, Y. (2006). The Safety Performance of Apartment Buildings : Empirical Evidence from Hong Kong [PhD Thesis]. The University of Hong Kong.

Zimmerman, A., \& Martin, M. (2001). Post-occupancy evaluation: benefits and barriers. Building Research \& Information, 29(2), 168-174. doi:10.1080/09613210010016857 